\section{Risk assessment terminology: risk communication part 2}

\author{
Gaetano Liuzzo, ${ }^{1}$ Stefano Bentley, ${ }^{2}$ \\ Federica Giacometti, ${ }^{3}$ Silvia Piva, ${ }^{3}$ \\ Andrea Serraino ${ }^{3}$
}

'Modena Local Health Unit, Carpi District, Carpi (MO); ${ }^{2}$ Department of Veterinary

Science, University of Parma, Parma;

${ }^{3}$ Department of Veterinary Medical

Sciences, Alma Mater Studiorum-

University of Bologna, Ozzano dell'Emilia

(BO), Italy

\begin{abstract}
The paper describes the terminology of risk communication in the view of food safety: different aspects of risk perception (perceived risk, media triggers, the psychometric paradigm, fright factors and cultural determinants of risk perception) are described. The risk profile elements are illustrated in the manuscript: hazard-food commodity combination(s) of concern; description of the public health problem; food production, processing, distribution and consumption; needs and questions for the risk assessors; available information and major knowledge gaps and other risk profile elements.
\end{abstract}

\section{English version}

\section{Public}

The general public, consumers and communities of interest, such as environmental, consumer or health organisations, as well as industry, scientific and professional associations (Santé Canada, 2000).

\section{Network}

A system in which, in specific sectors, a number of people representing different interests and points of view interact with one another by exchanging resources and information in order to achieve compromises between the various interests at stake.

\section{Media triggers}

Some indicators, if present, can guarantee the media coverage of a possible risk for public health. The risk is more likely to become a major story if some factors are prominent or can readily be made to become so. These factors are the so-called media triggers and include: issues that deserve blame (there is some fault or responsibility); presumption of secrecy and cover-up attempts; emotionally relevant human interest (heroes, culprits, rascals, fools, or victims are clearly identifiable); signal value (the story as a portent of further ills); links with existing hot issues or personalities; conflict and controversy; number and type of people threatened by the risk (link with the neighbour or average guy); strong visual impact; links with sex/blood (Bennett, 1999).

\section{Perceived risk}

Risk resulting from an individual, subjective assessment, based on a mental representation (Rumiati and Savadori, 1999).

\section{Psychometric paradigm}

Risk assessment by non-experts depends on the point of view of the individual as regards specific knowledge and its relationship with the environment. To study this perspective Slovic (1987) has proposed a psychometric paradigm that consists of a list of the main aspects that the individual takes into account in assessing risk and consequently judge its acceptability. The following aspects are considered: is the risk individually controllable? Is it imposed or voluntary? Is it fair or unfair (created by someone, but suffered by others)? It is a known or unknown threat or mysterious? Are the consequences immediate or deferred in time with a burden on future generations? Are the consequences global or local? What is the number of people exposed? Can the authorities and the experts' assessment be trusted? According to Slovic (1987), trust has a key role in the complexity of elements and influences all other aspects. Trust granted to the authorities is then dependent on political affiliations and education status (Peretti-Watel, 2001). The lower the trust given by the consumer to the authorities and experts, the lower the feeling of being able to control the risk and the greater the feeling of suffering unfairly the consequences of exposure to that risk. The psychometric paradigm allows then a sort of mapping of the various risks on the basis of these characteristics giving a specific profile to each risk (Rumiati et al., 1999).

\section{Risk perception \\ Cultural determination}

The diversity of points of view with regard to risk not only depends on the level of technical expertise that each of us has, and is not limited to an opposition between who is experienced and who is profane. The opinions and the attitude to the risk that everyone has depend on the individual values and culture, from what gives meaning and significance to particular risks. And this cultural bias often renders ineffective any scientific argument or warning. Anthropologist Mary Douglas has conceptualised four types of organisation, four cultural types expressing common values: i) hierarchical structure, ii) individualism, iii)
Correspondence: Gaetano Liuzzo, Modena Local Health Unit, Carpi District, Piazzale Donatori di Sangue 3, 41012 Carpi (M0), Italy.

Tel: +39.051 .2097323 .

E-mail: vet.liuzzo@internetpiu.com

Key words: Risk communication; Risk perception; Risk profile.

Received for publication: 26 November 2015 . Accepted for publication: 27 November 2015.

This work is licensed under a Creative Commons Attribution-NonCommercial 4.0 International License (CC BY-NC 4.0).

(C) Copyright G. Liuzzo et al., 2016

Licensee PAGEPress, Italy

Italian Journal of Food Safety 2016; 5:5649

doi:10.4081/ijfs.2016.5649

egalitarian sectarianism, iv) isolation.

Hierarchical structure is represented by the archetype of the bureaucracy (core community) and is characterised by a clear disjunction both within the group (hierarchical relationship), and between that and other social groups. The hierarchical structure respects institutional scientific knowledge, order, conventions and traditions and has confidence in prevention campaigns and information, as well as official marks. It is based on a formal regulation that allows to reduce uncertainty and which tends to give standard answers to problems. According to this view, the body is protected by a double $c a s$ ing (physical and social) and the individual has fewer worries about his protection. There's a strong pressure on the individual from the group. Members of this group are inclined to focus on the disadvantages of other people's diseases rather than on their own.

Individualism is an organisation with a low structural level, and the boundaries between its components and other organisations have little or no definition. The archetype is represented by the company in an ideal market. His belief in institutional scientific knowledge is firm, but goes beyond: in fact, the uncertainty is considered as an opportunity to demonstrate its capacity and its control. Faced with a risk, this cultural type proves itself prone to a prevention that emphazises individual responsibility rather than a constricting regulations. Risk can be managed on an individual basis, controlling gateways to diseases and infections. This makes the group particularly sensitive to prevention and awareness campaigns.

Egalitarian sectarianism is characterised by mistrust of knowledge validated by the core community and has a tendency to rely upon their own sources. It believes in the individual 
who can acquire knowledge and make discoveries quickly and take those elements that the hierarchical structure judges less credible. Its archetype can be found in religious sects, ecologists' movements and small organisations that are isolated from the rest of society. The group puts a strong pressure on the single member, who in return shows a strong sense of belonging and identification as in the hierarchical structure. The member of this category considers that the body is protected by a dual wrap, physical and social, but unlike the hierarchical structure he believes that the individual should first protect his group, and then himself.

Individuals identified in the isolation type of structure are subdued to the rest of society and are unable to organise and develop a sense of identity that may define the boundaries. They are the banned of contemporary industrial society. They do not have or do not develop consolidated views of what science is. They suspect the economic interests of the core community and of the individualist so that everything conspires against them. Distinguishing features are: the resignation, lack of education, fatalism. Their key concept is to have a porous, permeable and therefore vulnerable body (Douglas, 1991).

\section{Fright factors}

Exploring the concept of risk from an emotional-perceptive approach led Sandman (1987) to express risk as a result of the following symbolic expression: $\mathrm{R}=\mathrm{P} \times 0$ where $R$ is the risk, $P$ the danger and 0 the degree of offense. According to this perspective, in risk assessment, the emotional and psychological impact on the people involved in the risk should be taken into account first. The component of offense (outrage) will in turn be dependent on subjective variables related to emotional experiences, the perceptive distortion (perceptive bias) of the risk and the socio-cultural component of the exposed population. The variables influencing the extent of the offense (cd. fright factors) are diverse and can be categorised from the less risky to the more risky. Features like voluntary, familiar, manageable, fair, non-fatal, etc. can be classified as less risky. Features involuntary, unfamiliar, uncontrollable, unfair, fatal are classified as more risky (Norsa, 2002).

\section{Risk profile}

The description of a food safety problem and its context in order to identify the relevant elements of hazard or risk for making decisions on risk management (CAC, 2007). A risk profile may include descriptive elements, using readily accessible information: a concise description of the food safety issue; any information about the hazard (general description, listing knowledge on the relationship between hazard and adverse health effects); any feature of the pathogen/human relationship; any information about exposure to the hazard, e.g. routes of exposure, prevalence, characteristics of the hazard; levels of hazard throughout the food chain; possible control measures; information on the adverse health effects on humans, e.g. types and severity of adverse health effects; subsets of populations at increased risk; prevalence and incidence data from public health surveillance; collection of other information relevant to risk management decision-making; perceptions of the food safety issue by interested parties; practical considerations (economic, technical, political, legal); considerations for risk assessors (FAO/OMS, 2002).

\section{Elements of risk profile}

The risk profile is a short working document, presenting the elements of a risk management issue in order to facilitate decision making by the risk manager in relation to the needs and expectations of the proposed management work. The risk profile elements are: i) hazard-food commodity combination(s) of concern; ii) description of the public health problem (including characteristics of the disease and characteristics of the foodborne transmission); iii) food production, processing, distribution and consumption; iv) other risk profile elements; $v$ ) risk assessment needs and questions for the risk assessors; vi) available information and major knowledge gaps. Details are reported in Table 1.

\section{Italian version}

\section{Pubblico}

Il grande pubblico, i consumatori e le comunità di interesse, come le associazioni ambientaliste dei consumatori o della salute, così come le associazioni industriali, scientifiche e professionali (Santé Canada, 2000).

\section{Rete o network (concetto polito- logico)}

Inteso come un meccanismo nel quale, in specifici settori, un certo numero di soggetti che rappresentano punti di vista ed interessi diversi interagiscono l'uno con l'altro scambiandosi risorse ed informazioni al fine di raggiungere compromessi tra $\mathrm{i}$ vari interessi in gioco.

\section{Indicatori che innescano l'interesse dei media (media triggers)}

Si tratta d'indicatori che se presenti fanno sì che un rischio per la salute pubblica sia mediatizzato. Questi fattori, infatti, rendereb- bero interessanti per i media la storia e darebbero la certezza che la stessa abbia una particolare visibilità; un possibile rischio può diventare uno scoop giornalistico se i fattori elencati sono presenti o se sia possibile fare in modo che essi diventino preminenti. I cosidetti. Media triggers sono: questioni che meritano biasimo (vi è qualche colpa 0 responsabilità), presunzione di segreti e tentativi di insabbiamento, interesse umano emotivamente rilevante (sono identificabili chiaramente gli eroi, i colpevoli, i mascalzoni, i gonzi, i babbei oppure le vittime), legami con pratiche scottanti 0 personalità in vista, conflitto e controversia, valore di avvertimento nel senso che il fatto costituisce presagi di altri mali futuri, sono minacciate numerose persone dal rischio e queste persone appartengono a categorie dell'uomo comune o del vicino di casa, forte impatto visivo (immagini di sofferenza, la sofferenza si tocca con mano), legami con il sesso e il sangue (Bennett, 1999).

\section{Paradigma psicometrico}

La valutazione del rischio da parte dei non esperti dipende dal punto di vista del singolo nei confronti della conoscenza e della sua relazione con l'ambiente. Per studiare questa prospettiva Slovic (1987) ha proposto un paradigma psicometrico che consiste in una lista dei principali aspetti che l'individuo prende in considerazione per valutare un rischio e giudicarne di conseguenza la sua accettabilità. Gli aspetti che si considerano sono i seguenti: il rischio è individualmente controllabile?; il rischio è imposto 0 volontario?; il rischio è giusto 0 ingiusto (prodotto da alcuni e sopportato da altri); è una minaccia conosciuta 0 misteriosa?; le conseguenze del rischio sono immediate 0 differite nel tempo con ripercussioni sulle generazioni future?; le conseguenze sono planetarie 0 locali?; l'incidenza è nefasta per le generazioni future?; qual è il numero delle persone esposte?; le autorità e la valutazione degli esperti meritano fiducia? La fiducia, secondo Slovic, ha un ruolo centrale nella complessità degli elementi e condiziona tutti gli altri aspetti. La fiducia accordata alle autorità è poi dipendente dalla preferenza politica riguardo al potere ed il livello scolare (Peretti-Watel, 2001). Minore sarà la fiducia accordata dal consumatore alle autorità ed agli esperti, minore sarà la sensazione di poter controllare il rischio e maggiore la sensazione di subire ingiustamente le conseguenze dell'esposizione a quel rischio. Il paradigma psicometrico permette poi di ottenere una mappatura dei diversi rischi sulla base di queste caratteristiche conferendo a ciascun rischio un profilo specifico (Rumiati et al., 1999).

\section{Rischio percepito}

Rischio prodotto della valutazione degli individui, soggettivo, basato sulla rappresentazione mentale (Rumiati et al., 1999). 


\section{Percezione del rischio \\ Determinazione culturale}

La diversità dei punti di vista relativi al rischio non dipende solo dal livello di competenza tecnica che ciascuno di noi ha e non si limita solamente ad una opposizione tra chi è esperto e chi invece è profano. Le opinioni e l'attitudine al rischio che ognuno di noi ha dipendono dai valori e dalla cultura individuale, da ciò che dà senso e significato particolare ai rischi. E' questa distorsione culturale che spesso rende inefficaci gli argomenti 0 avvisi scientifici. L'antropologa Mary Douglas ha concettualizzato quattro tipologie organizzative portatrici di valori comuni che costituiscono quattro tipi culturali: la struttura gerarchica, l'individualismo, il settarismo egalitario, l'isolamento.

La struttura gerarchica è rappresentata dall'archetipo della burocrazia (comunità centrale) ed è caratterizzato dalla demarcazione netta sia all'interno del gruppo (relazione gerarchica), che fra questi ed altri gruppi sociali. La struttura gerarchica ha rispetto del sapere scientifico istituzionale, dell'ordine, delle convenzioni e delle tradizioni e ha fiducia nelle campagne di prevenzione e di informazione, nonché dei marchi ufficiali. Si regge su di una regolazione formale che le permette di ridurre l'incertezza e soprattutto che omologa le risposte ai problemi. Secondo questa concezione il corpo si trova protetto da un duplice involucro fisico e sociale e l'individuo deve preoccuparsi meno della sua protezione. Forte è la pressione del gruppo sul singolo individuo. I membri di questo gruppo sono portati a focalizzare gli svantaggi sulle malattie degli altri piuttosto che sulle proprie.

Table 1. Details of the risk profile elements.

N. Risk profile elements

1 Hazard-food commodity

combination(s)

of concern

2 Description of the public health problem [description of the hazard including key attributes that are the focus of its public health impact (e.g., virulence characteristics, thermal resistance, antimicrobial resistance)]

\section{Characteristics of the disease}

if po

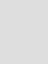

Characteristics of the foodborne transmission
Description

Hazard(s) of concern; description of the food or food product and/or condition of its use with which problems (foodborne illness, trade restrictions) due to this hazard have been associated

Susceptible populations; annual incidence rate in humans including, if possible, any differences between age and sex; outcome of exposure; severity of clinical manifestations (e.g., case-fatality rate, rate of hospitalization); nature and frequency of long-term complications; availability and nature of treatment; percentage of annual cases attributable to foodborne transmission

Epidemiology and etiology of foodborne transmission, including characteristics of the food or its use and handling that influences foodborne transmission of the hazard; foods implicated; frequency and characteristics of foodborne outbreaks; frequency and characteristics of foodborne sporadic cases; epidemiological data from outbreak investigations; regional, seasonal, and ethnic differences in the incidence of foodborne illness due to the hazard; economic impact or burden of the disease if readily available; medical, hospital costs; working days lost due to illness, etc.

Characteristics of the commodity (commodities) involved and that may impact on risk management; description of the farm to table continuum including factors which may impact the microbiological safety of the commodity (i.e., primary production, processing, transport, storage, consumer handling practices); what is currently known about the risk, how it arises with respect to the commodity's production, processing, transport and consumer handling practices, and who it affects; summary of the extent and effectiveness of current risk management practices including food safety production/processing control measures, educational programs, and public health intervention programs (e.g., vaccines); identification of additional risk mitigation strategies that could be used to control the hazard

The extent of international trade of the food commodity; existence of regional/international trade agreements and how they may affect the public health impact with respect to the specific hazard/commodity combination(s); public perceptions of the problem and the risk; potential public health and economic consequences of establishing Codex MRM guidance

5 Risk assessment needs and questions for the risk assessors Initial assessments of the need and benefits to be gained from requesting an MRA, and the feasibility that such an assessment could be accomplished within the required time frame; if a risk assessment is identified as being needed, recommended questions that should be posed to the risk assessor

6 Available information and major knowledge gaps
Provide, to the extent possible, information on: existing national MRAs on the hazard/commodity combination(s); other relevant scientific knowledge and data that would facilitate MRM activities including, if warranted, the conduct of an MRA; existing Codex MRM guidance documents (including existing Codes of Hygienic Practice and/or Codes of Practice); national governmental and/or industry codes of hygienic practice and related information (e.g., microbiological criteria) that could be considered in developing a (Codex) MRM guidance document; sources (organizations, individual) of information and scientific expertise that could be used in developing (Codex) MRM guidance document; areas where major absences of information exist that could hamper MRM activities including, if warranted, the conduct of an MRA 
L'individualismo è una organizzazione poco strutturata ed i confini fra i componenti e altre organizzazioni sono poco o per nulla definiti. L'archetipo è rappresentato dall'impresa in un contesto di mercato ideale. Il suo credere nel sapere scientifico istituzionale è consolidato, ma va oltre, considera infatti l'incertezza come una opportunità per dimostrare le sue capacità ed il suo controllo Di fronte ad un rischio, questo tipo culturale si dimostra favorevole ad una prevenzione che privilegi la responsabilizzazione individuale piuttosto che una regolamentazione di tipo costrittivo. Crede di poter gestire il rischio in modo individuale sorve- gliando per così dire i punti di accesso di malattie e d'infezioni; ciò lo rende particolarmente sensibile alla campagne di prevenzione e sensibilizzazione.

Il settarismo egalitario si caratterizza per la sfiducia verso il sapere validato dalla comunità centrale ed ha la tendenza a mobilitare le pro-

Tabella 1. Dettagli degli elementi del profilo di rischio.

N. Elementi del profillo di rischio

1 Combinazione/i pericolo/alimento

2 Descrizione del problema di salute pubblica [descrizione del pericolo comprese le caratteristiche chiave che sono al centro dell'attenzione per l'impatto sulla salute pubblica (caratteristiche di virulenza, resistenza termica, antibioticoresistenza, ecc.)]

Caratteristiche della malattia

Caratteristiche della trasmissione per via alimentare Descrivione

Pericolo e descrizione dell'alimento o prodotto alimentare e della condizione di uso con la quale si hanno problemi riferibili a quel pericolo (malattia trasmessa con gli alimenti, restrizioni commerciali)

Popolazione suscettibile; tasso di incidenza annuale negli uomini con inclusione, Differenze per sesso ed età; conseguenze dell'esposizione; gravità delle manifestazioni cliniche (tasso di letalità, tasso di ospedalizzazione); disponibilità e natura dei trattamenti; percentuale dei casi annuali che si possono attribuire alla trasmissione con alimenti Epidemiologia ed eziologia della trasmissione alimentare, incluse le caratteristiche dell'alimento,

del suo uso e manipolazione che possono influenzare la trasmissione del pericolo per mezzo dell'alimento; alimenti implicati; frequenza e caratteristiche dei focolai; frequenza e caratteristiche dei casi sporadici di malattia trasmesse attraverso gli alimenti; dati epidemiologici derivanti da investigazioni in corso di focolai; differenze regionali, etniche, stagionali sulla incidenza delle malattie trasmesse dagli alimenti e dovute al pericolo; impatto economico o peso della malattia, se disponibile: costi medici e di ospedalizzazione; giorni di lavoro persi a causa della malattia

3 Produzione, processo produttivo, distribuzione

\section{$4 \quad$ Altri elementi}

Caratteristiche del prodotto o dei prodotti implicati che possono influire sulla gestione dei rischi; descrizione della catena alimentare (dalla terra alla tavola) includendo i fattori che possono influire sulla innocuità microbiologica del prodotto (produzione primaria, processo produttivo, trasporto, stoccaggio, manipolazione da parte del consumatore); ciò che attualmente è conosciuto circa il rischio, come si origina rispetto alla produzione, al processo e al trasporto, così come rispetto alle pratiche di manipolazione da parte del consumatore che ne è affetto; riassunto sulla estensione ed efficacia delle misure di gestione del rischio, incluso le misure di controllo lungo il processo di produzione, i programmi educazionali e gli interventi di salute pubblica (vaccinazioni); identificazione delle strategie addizionali per la riduzione dei rischi che possono essere utilizzate per la riduzione del pericolo

Estensione del mercato internazionale per il prodotto alimentare; esistenza di trattati commerciali regionali o internazionali e come questi potrebbero inte essare l'impatto sulla salute pubblica in rispetto alla combinazione specific pericolo/prodotto; percezione pubblica circa il rischio; possibili conseguenze per la salute pubblica e l'economia dell'industria, per il Codex e per il documento sopra la gestione del rischio microbiologico

$5 \quad$ Necessità della valutazione dei rischi e domande dei risk assessors Iniziale valutazione delle necessità e dei benefici da ottenere da una richiesta di valutazione del rischio così come della possibilità che la valutazione sia realizzata nel tempo richiesto; se si stabilisce una valutazione del rischio è necessario stabilire le domande da porre ai valutatori del rischio

6 Informazioni disponibili e lacune del sapere

Procurare nel limite del possibile, le informazioni circa i seguenti punti: valutazione del rischio microbiologico attuali circa la/le combinazioni pericolo/i/prodotto/i; altre conoscenze scientifiche rilevanti che possono facilitare le attività di gestione del rischio, inclusa, se necessario, una realizzazione di valutazione del rischio; esistenza di documenti guida (Codex) sulla gestione del rischio (che includano Codici di Buona pratica igienica, ecc.); codici di buona pratica igienica di governi nazionali, di industrie e informazioni (criteri microbiologici) che possono considerarsi nella preparazione di un codice sulla gestione del rischio; sorgenti di informazione (organizzazioni, individuali) e di conoscenza scientifica, esperti che possono essere utilizzate nella preparazione di un documento guida (Codex) sulla gestione del rischio; aree dove maggiori sono le assenze di informazione che possono essere di ostacolo per le attività di gestione, con la inclusione, se opportuna, di una valutazione del rischio 
prie sorgenti del sapere. Crede nell'individuo capace di acquisire sapere e fare scoperte rapidamente ed adotta le conoscenze che la struttura gerarchica giudica meno credibili. Trova il suo archetipo nelle sette religiose, nei movimenti ecologisti e nelle piccole organizzazioni che si isolano dal resto della società. Il gruppo esercita una forte pressione sul singolo componente che manifesta un forte senso di appartenenza e di identificazione come la struttura gerarchica. L'appartenente a questa categoria considera che il corpo è protetto da un duplice involucro fisico e sociale ma, a differenza della struttura gerarchica, crede che l'individuo debba proteggere prima il suo gruppo e quindi se stesso.

Gli individui identificabili nella struttura isolamento sono subordinati al resto della società e sono incapaci ad organizzarsi e a sviluppare un sentimento di identità che possa definire dei confini. Sono gli esclusi della società contemporanea industriale. Non hanno o comunque non sviluppano opinioni consolidate su cosa sia la scienza. Sospettano interessi economici della comunità centrale e dell'individualista tanto che tutto complotta contro di loro. Elementi caratterizzanti sono: la rassegnazione, l'assenza di scolarità, il fatalismo. Il loro concetto cardine è di avere un corpo poroso, permeabile e dunque vulnerabile (Douglas, 1991).

\section{Fattori di terrore e/o di indignazione}

L'esplorazione del concetto di rischio dalla prospettiva percettivo-emozionale, ha portato Sandman (1987) ad esprimere il rischio come risultato della seguente espressione simbolica: $\mathrm{R}=\mathrm{P} \times 0$ dove $\mathrm{R}$ è il rischio, $\mathrm{P}$ il pericolo e 0 il grado di offesa. Secondo questa prospettiva, nella valutazione del rischio, si tiene conto soprattutto delle ripercussioni emotive e psicologiche sulla popolazione coinvolta nel rischio. La componente di offesa (outrage) risulterà a sua volta dipendente da variabili soggettive correlate ai vissuti emozionali, alla distorsione percettiva (bias percettiva) dell'entità del rischio e dalla componente socio-culturale della popolazione esposta al rischio. Le variabili che intervengono sull'entità dell'offesa (fright factors) sono diversi e possono essere categorizzati in funzione del meno rischioso rispetto al più rischioso. Ad es. i caratteri volontario, familiare, controllabile, equo, non fatale, ecc sono propri della categoria meno rischioso. I caratteri involontario, non familiare, incontrollabile, ingiusto, fatale sono propri della categoria più rischioso (Norsa, 2002).

\section{Profilo del rischio}

Corrisponde alla descrizione di un problema di sicurezza degli alimenti e del suo contesto con l'obiettivo di identificare gli elementi di pericolo o di rischio pertinenti per la presa di decisioni in materia di gestione dei rischi (CAC, 2007). Il profilo di un rischio può incorporare degli elementi descrittivi ottenibili da informazioni facilmente accessibili: la descrizione concisa del problema; le informazioni che riguardano il pericolo (descrizione generale che indica le conoscenze sulla relazione fra il pericolo e gli effetti sulla salute); la menzione di tutte le caratteristiche che riguardano la relazione fra agente patogeno e soggetto umano; informazioni che riguardano l'esposizione al pericolo così come la via d'esposizione, la prevalenza, le caratteristiche del pericolo; i livelli di pericolo lungo la catena alimentare; le misure di lotta individuabili; la raccolta d'informazioni sugli effetti avversi per la salute umana quali il tipo di effetto, la gravità; i sottoinsiemi di popolazione colpiti; i dati concernenti la prevalenza e l'incidenza ottenuti durante l'attività di sorveglianza sanitaria; la raccolta di altre informazioni che riguardano la presa di decisioni in materia di gestione dei rischi; la percezione pubblica del problema; considerazioni di ordine pratico che coinvolgono aspetti economici, tecnici, politici e giuridici; le considerazioni che andranno sottoposte ai valutatori del rischio (FAO/OMS, 2002).

\section{Elementi di profilo del rischio}

Il profilo del rischio è un breve documento di lavoro che presenta gli elementi di un problema di gestione del rischio con l'obiettivo di facilitare la presa di decisione da parte del gestore del rischio relativamente alla necessità ed alle attese del lavoro di gestione proposto. Sono elementi del profilo: i) combinazione/i pericolo/alimento ; ii) descrizione del proble- ma di salute pubblica; iii) produzione, processo produttivo, distribuzione; iv) altri elementi; v) necessità della valutazione dei rischi $\mathrm{e}$ domande dei risk assessors; vi) informazioni disponibili e lacune del sapere. Tutti i dettagli sono riportati nella Tabella 1.

\section{References}

Bennett P, 1999. Understanding responses to risk: some basic findings. In: Bennett $P$, Calman K, eds. Risk communication and public health. Oxford University Press, New York, NY, USA, pp 3-19.

CAC, 2007. CAC/GL 63-2007. Annex II on guidance on microbiological risk management metrics adopted in 2008. Codex Alimentarius Commission, Rome, 2008.

Douglas M, 1991. Come percepiamo il pericolo. Antropologia del rischio. Feltrinelli, Milan, Italy.

FA0/0MS, 2002. Principes et lignes directrices en vue de l'incorporation de l'évaluation du risque microbiologique dans l'élaboration de normes, de lignes directrices et de textes connexes en matière de sécurité sanitaire des aliments. Available from: www.fao.org/3/a-y4302f.pdf

Norsa L, 2002. Crisis management. Edizioni Giuridiche Simone, Naples, Italy.

Peretti-Watel P, 2001. La société du risque. La Découverte, Paris, France.

Rumiati R, Savadori L, 1999. Percezione del rischio e rischio tecnologico-professionale. Risorsa Uomo 6:1.

Sandman PM, 1987. Risk communication: facing public outrage. Available from: http://www.psandman.com/articles/facing.htm

Santé Canada, 2000. Participation du public: cadre et lignes directrices. Bureau de la participation des consommateurs et du public Santé Canada, Ministre de Travaux publics et Services gouvernementaux du Canada, Ottawa, Canada.

Slovic P, 1987. Perception of risk. Science 236:280-5. 